\title{
THE POLICE OF THE SEVERAN DYNASTY TOWARDS CHRISTIANITY
}

\section{Petrechko O. M.}

\section{INTRODUCTION}

Many aspects of the reign of Emperor Septimius Severus are still controversial in the modern historiography of ancient Rome. This thesis is valid for a wide range of issues, concerning both home and foreign policy of the founder of the Severan dynasty. There is no consensus among historians on the issues of Septimius Severus's reforms and their influence on the development of the Principate system.

Edward Gibbon had no doubt that Septimius Severus was an absolute monarch whose interests coincided with that of the Roman people: "Severus considered the Roman Empire as his property, and had no sooner secured the possession than he bestowed his care on the cultivation and improvement of so valuable an acquisition". Mason Hammond was of the same opinion. In his view, Septimius Severus replaced the Principate of Augustus, in which the Senate was the nominal head and the real co-ruler of the Empire, with a military and dynastic monarchy, with total concentration of power in the hands of the ruler ${ }^{2}$. Other researchers share the same opinion ${ }^{3}$. Ivan Sergeev believes that the founder of the Severan dynasty "improved" the system of the Principate. The scientist considers Severus's military policy not as an attempt to thank the soldiers for their help in the struggle for power, but as an attempt to strengthen the position of the central government and to strengthen the loyalty of soldiers to the emperor ${ }^{4}$.

The problem of the government's policy on Christianity during the period of the Severan dynasty remains obscure. A vivid example of controversy is the Septimius Severus edict concerning the Jews and the Christians. There is no consensus on the time of its publication and the

\footnotetext{
${ }^{1}$ Gibbon E. The decline and fall of the Roman Empire. New York : Peter Fenelon Cooper, 1899. Vol. I. P. 144.

${ }^{2}$ Hammond M. Septimius Severus, Roman bureaucrat. Harvard Studies in Classical Philology. 1940. Vol. 51. P. 137

${ }^{3}$ Fishwick D. The Imperial Cult in the Latin West : studies in the ruler cult of the western provinces of the Roman Empire. Leiden : Brill, 1987. - Vol. 1.2. P. 335.

4 Сергеев И.П. Римская империя в III веке нашей эры. Проблемы социально-политической истории. Харьков : Майдан, 1999. С. 56.
} 
influence it had on the development of Christianity ${ }^{5}$, whether this was an edict, as we also think, or a rescript ${ }^{6}$, there even have been expressed doubts regarding the very fact of the existence of this edict ${ }^{7}$. It should be noted that religious policy in fact was an important component of the Principate of Septimius Severus. The analysis of recent research and publications reveals that the problem of the relationship between Christianity and Roman authorities is largely considered in the context of the persecutions of the Christians. This seems justified, given that the study of the causes of these persecutions allows us to understand the logic of the integration of Christianity into Roman society and the evolution of its relationship with the Roman authorities. By carefully examining the legal, political and religious aspects of the attitude of the Romans towards the Christians, scientists are trying to find an acceptable solution to the problem of the persecution of the Christians ${ }^{8}$. There's a lot of talk with regard to the possibility of the existence of a general law adopted during the reign of Nero or Domitian, in force in the entire empire, prohibiting the Christianity. Proponents of the theory of coercitio believe that Christians were punished by Roman officials without resorting to special legislation, founded on their authority based on their imperium. It is also stated that the persecution of the Christians took place on the basis of existing laws against specific crimes: infanticide, incest, magic, etc. In addition, there has been expressed an opinion that the government policy on Christianity depended on the wishes and views of the incumbent emperor ${ }^{9}$. Obviously John Crake was right to call this controversy "endless" ". Adrian Sherwin-

5 Лебедев А. П. Эпоха гонений на христиан и утверждение христианства в Греко-римском мире при Константине Великом. Москва : Изд-й отдел Спасо-Преображенского Валаамского Ставропигиального монастыря, 1994. С. 231-237; Федосик В.А. Киприан и античное христианство. Минск : Университетское, 1991. С. 15; Platnauer M. The life and reign of the Emperor Lucius Septimius Severus. London : Oxford University Press, 1918. P. 154.

${ }^{6}$ Frend W.H.C. Persecutions: genesis and legacy / The Cambridge History of Christianity / Ed. by Margaret M. Mitchell \& Frances M. Young. Cambridge : Cambridge University Press, 2006. Vol. I : Origins to Constantine. P. 511; Keresztes P. The Emperor Septimius Severus : a Precursor of Decius Historia. 1970. Bd. 19, H. 5. P. 573-574; Plescia J. On the persecution of the Christians in the Roman Empire. Latomus. 1971. Fasc. 1. T. 30. P. 123.

${ }^{7}$ Крист К. История времен римских императоров от Августа до Константина : в 2-х т. Ростов н/Д. : Феникс, 1997. T. 2. С. 345; Barnes T.D. Legislation against the Christians. The Journal of Roman Studies. 1968. Vol. 58, Parts 1-2. P. 41; Suski R. Jowisz, Jahwe i Jezus : religie w Historia Augusta. Warszawa : Wydawnictwo Naukowe Sub Lupa, 2014. P. 261.

8 Janssen L.F. «Superstitio» and the Persecution of the Christians. Vigiliae Christianae. 1979. № 2, Vol. 33. P. 131.

9 Лебедев А.П. Эпоха гонений на христиан и утверждение христианства в Греко-римском мире при Константине Великом. Москва : Изд-й отдел Спасо-Преображенского Валаамского Ставропигиального монастыря, 1994. С. 5-36; Bryan C. Render to Caesar : Jesus, the early church and the Roman superpower. Oxford : Oxford University Press, 2005. P. 116; Canfield L.H. The early persecutions of the Christians. New York : Columbia University, 1913. P. 25; Ramsay W.M. The Church in the Roman Empire. London : Hodder and Stoughton, 1893. P. 209; Sherwin-White A.N. The early persecutions and Roman law again. The Journal of Theological Studies. 1952. Vol. III, issue 2. P. 199.

${ }^{10}$ Crake J.E.A. Early Christians and Roman law. Phoenix. 1965. № 1. Vol. 19. P. 62. 
White thoroughly looked into the aforementioned theories in the appendix to his comments on the letters of Pliny the Younger ${ }^{11}$.

\section{Hostility of the Romans to the Christians and Septimius Severus}

The formation of Christianity and its early history are closely linked to ancient Rome. Christian communities arose both in Rome itself and in provincial cities; Christian texts were written in Latin and in Greek, which ensured the widest possible spread of Christian doctrine, both in the West and in the Eastern Provinces. The Roman Empire provided a broad political, social and religious environment for the emergence of early Christianity $^{12}$. Actually, Christianity transformed into a world culture phenomenon due to the realities of the existence within the Roman Empire, where religious life was not private, but a state affair. Edward Gibbon stated five causes of the rapid growth of the Christian Church:

" 1 . The inflexible, and, if we may use the expression, the intolerant zeal of the Christians, derived, it is true, from the Jewish religion, but purified from the narrow and unsocial spirit, which, instead of inviting, had deterred the Gentiles from embracing the law of Moses.

2. The doctrine of a future life, improved by every additional circumstance which could give weight and efficacy to that important truth.

3. The miraculous powers ascribed to the primitive church.

4. The pure and austere morals of the Christians.

5. The union and discipline of the Christian republic, which gradually formed an independent and increasing state in the heart of the Roman Empire" 13 .

However, the process of Christianization of the Roman Empire was complex and ambiguous. In the first three centuries the Christians were persecuted by the Roman authorities. The study of the interaction between the Christianity and the authorities is extremely important both to understand the internal policies of the Roman government and to understand the essence of Christianization. In historiography, we even can find the identification of Christianization with the process of interaction between Christianity and various secular institutions ${ }^{14}$. Ambrogio Donini

\footnotetext{
${ }^{11}$ Sherwin-White A.N. The letters of Pliny : a historical and social commentary. Oxford : Clarendon Press, 1966. P. 772-787.

${ }^{12}$ Klauck H.J. The Roman Empire / The Cambridge History of Christianity / Ed. by Margaret M. Mitchell \& Frances M. Young. Cambridge : Cambridge University Press, 2006. Vol. I : Origins to Constantine. P. 69.

${ }^{13}$ Gibbon E. The decline and fall of the Roman Empire. New York : Peter Fenelon Cooper, 1899. Vol. I. P. 505-506.

14 Казаков М.М. Проблема христианизации Римской империи. Исследования по зарубежной истории. Смоленск, 2000. С. 196-197. Режим доступа : http://ancientrome.ru/publik/article.htm?a=140 5377993.
} 
believes that Christianization of the empire was actually a merger of Christianity with the new state institutions ${ }^{15}$.

At the end of the first century BC necessary prerequisites for the successful establishment of Christian ideology in Roman society were formed. In this context, it should be mentioned that the Roman, who was a true follower of traditional Roman beliefs, was, more likely, ready to accept the basic postulates of the Christian religion. It was quite common to believe in the immortality of the soul ${ }^{16}$. The veneration of the souls (manes) of their ancestors was a commonplace for the Romans. The emperor, as a rule, during his lifetime was awarded the title pater patriae father of the Fatherland. Naturally, the deceased emperor had the divine honors. John Kenrick reasonably good guessed that almost the universal introduction of epitaphs Diis Manibus, or abbreviation D.M. indicated general belief that the spiritual component of human nature continues to exist after death ${ }^{17}$. There is reason to believe that in the minds of the Romans, the souls of the dead relatives became younger deities - manes. The Roman writers told about the existence of the soul after death, such information we also find on the epitaphs ${ }^{18}$. So, for the Romans, the idea of the existence of the soul after the death of the body was not new. It was new that Christianity told not only about the existence of the soul after the death of the body, but also about the salvation of the soul. However, this fact, obviously, should not have caused a negative reaction in Roman society. Not surprisingly, at the end of the second century, the number of Christians increased significantly.

There was an opinion about the tendency towards a certain religious tolerance during the reign of the Severan dynasty ${ }^{19}$. Tertullian told us about the goodwill of Septimius Severus towards Christians (Tert. ad Scap. 4). Indeed, the beginning of the reign of Septimius Severus was peaceful for Christians. They joined the ranks of the Roman military forces more actively, and even baptized Christians were enlisted in the army ${ }^{20}$. In all regions of the Roman Empire, there is a lot of evidence of the enrolment of Christians in military service, at least since the middle of the second

15 Донини А. У истоков христианства (от зарождения до Юстиниана). М. : Политиздат, 1989. С. 171 .

16 Moore C.H. Pagan ideas of immortality during the Early Roman Empire. Cambridge : Harvard University Press, 1918. P. 41.

17 Kenrick J. Roman sepulchral inscriptions : their relation to archaeology, language, and religion. London ; York : John Russell Smith ; R. Sunter ; H. Sotheran, 1858. P. 52.

${ }^{18}$ Petrechko O. A burial rite of the Romans in the context of the ancient society conception of the soul // Проблеми гуманітарних наук : збірник наукових праџь Дрогобищького державного педагогічного університету ім. І. Франка. Серія «Історія». 2016. Випуск 38. Р. 246-267.

${ }^{19}$ Aubé B. Les chrétiens dans l'Empire Romain de la fin des Antonins au milieu du IIIe siècle. Paris : Didier et Cie, 1881. P. 62.

${ }^{20}$ Gero S. «Miles Gloriosus» : The Christian and military service according to Tertullian. Church History. 1970. № 3. Vol. 39. P. 291. 
century $^{21}$. This trend, in part, can be explained by the increase in the attraction of the military service due to the reforms of Septimius Severus. He increased the fee to the soldiers and, apart from other privileges, gave

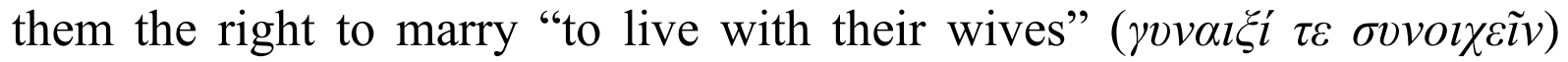
(Herodian 3.8.5). However, we should not exaggerate the mercantile motives in the desire of Christians to join the army. Previous increase in salaries to legionnaires was carried out by Emperor Domitian. The reform of Septimius Severus only made up for the inflation that had taken place since that time $\mathrm{e}^{22}$. In any case, there is a reason to believe that there was a tendency for more active participation of Christians in the official institutions of the Roman state, including the army.

A perceptible increase in the number of Christians inevitably increased the risk of conflict situations between them and the rest of society. This was facilitated by the intensification of factions with extremist views among the Christians, in particular, Montanists, who called themselves $\pi v \varepsilon v \mu \alpha \tau \imath \kappa o i$. These were extreme rigorists who opposed military service, urged their followers to become voluntary martyrs and did not approve of escape by flight, as opposed to the policy of the official Church. One of the follower of this faction, at a certain stage of his life, was a prominent Christian writer Tertullian. Montanists, who expressed extreme views in Christianity, gave enough reasons for association with the most dangerous forms of superstition, such as magic and divination. The typical terminology of Montanism ( $\chi \alpha \dot{\rho} \rho \iota \varsigma, \delta v ́ v \alpha \mu l \varsigma, \pi v \varepsilon \tilde{v} \mu \alpha$ ) is constantly found in magical papyri ${ }^{23}$. Among Christians there were also those, who personally engaged in magic and astrology (Tert. De idololat. 9). Legislation, however, severely punished those engaged in magic and divination. This is referred to by legal experts at the time of Severan dynasty: the soothsayers (vaticinatores), after being beaten with sticks, were expelled from the city (primum fustibus caesi civitate pelluntur). Particularly malicious ones were put into fetters or sent "to the island" (in insulam). Anyone who introduced new, unknown religious doctrines could have been exiled if he was of noble origin (honestiores) or executed if he was from commoners (humiliores) (Paulus. Sententiae. 5.21.1 - 2).

In our opinion, the hypothesis that precisely "Montanism was a prelude and cause of local persecution" 24 is sufficiently substantiated. Perhaps it was Montanists who were the catalyst for persecutions that

${ }^{21}$ Helgeland J. Christians and the Roman Army A. D. 173-337. Church History. 1974. № 2. Vol. 43. P. 156.

${ }^{22}$ Smith R.E. The army reforms of Septimius Severus. Historia. 1972. № 3. Bd. 21, H. 3. P. 492.

${ }^{23}$ Wypustek A. Magic, Montanism, Perpetua, and the Severan Persecution. Vigiliae Christianae. 1977. Vol. 51. № 3. P. 277.

${ }^{24}$ Phipps C.B. Persecution under Marcus Aurelius. An historical hypothesis. Hermathena. 1932. № 47. Vol. 22. P. 201. 
began in 197 in the Proconsul province of Africa. Paulus Orosius points out that Septimius Severus subjected Christians to the fifth, after Nero, persecution (quinta post Neronem persecutione Christianos excruciavit) and many of them suffered martyrdom (Oros. 7.17.4). Sources do not give us much information about these events. Our knowledge is based on the works of Tertullian: "To the Martyrs" (Ad martyras), "To the Nations" (Ad nationes) and "Apologeticus" (Apologeticum). All of them were written in 197, or a little later. According to the sources, those who were exposed in the practice of Christianity were thrown into jail. The prisoners were supported by the brothers in faith. Among them was Tertullian, who cheered prisoners with the words: "the prison gives the Christians what the desert gives the prophets" (Hoc praestat carcer Christiano, quod eremus prophetis). Tertullian listed "positive" sides of arrest: prisoners did not see strange gods, did not encounter their images etc. (Tert. Ad martyras. 2). The arguments cited by Tertullian should have prevented the apostasy, which was an inevitable companion for any persecution. Paul Keresztes rightly noted the anxiety of Tertullian about apostasy ${ }^{25}$.

Probably the initiator of the persecution in 197, as it often happened, was not the government, but the crowd. This is evidenced by the words of Tertullian. Shortly after the aforementioned events, he uses the phrase "an uneducated crowd" (indoctum vulgus), "a stupefied crowd" (caecum vulgus) (Tert. Apol. 22; 49). The hostility of the crowd was largely caused by the lack of reliable information about the essence of Christian doctrine and the distorted perceptions of the relationship between Christians. Tertullian says: "Some of you have dreamed that the donkey's head is our god" (Nam et, ut quidam, somniastis caput asininum esse deum nostrum) (Tert. Apol. 1). But if such concoction, as well as rumors of Thyestean feasts and Oedipal relations between Christians, had no real basis, the denial of the traditional gods was a reality. And it required a proper reaction from the rulers. Roman religion did not envisage the ban of other cults. Starting under the Flavian dynasty, the Roman coins testify the emergence of eastern cults that get an official status. But even under the Severan dynasty, which was favorable towards the Eastern cults, coins are devoted mainly to Roman gods ${ }^{26}$. The Romans perceived their religion as part of the state system. During the Principate period, emperors relied on traditional Roman religion and imperial cult. Therefore, the fact that Christians neglected traditional Roman religion was perceived as an encroachment on the basis of a state organization.

${ }^{25}$ Keresztes P. The Emperor Septimius Severus : a Precursor of Decius Historia. 1970. Bd. 19, H. 5.

${ }^{26}$ Абрамзон М.Г. Монеты как средство пропаганды официальной политики Римской империи. Москва : Институт археологии Российской Академии наук, 1995. С. 421-430. 
Another aspect of the conflict between Rome and Christians was the disrespect of the latter to the ancestral custom - mos maiorum (as it was treated by the Romans). In Rome, the observance of ancient customs was considered to be an inherent part of the duties of each individual citizen and the community as a whole. The introduction of the Principate was accompanied by a struggle for the revival of ancient traditions, which was supposed to reduce foreign influences. At the same time, the Romans endorsed the respect for strict adherence to tradition by other peoples, as can be seen from the example of the assessment given by Valerius Maximus to Massilians: "Inde Massilienses quoque ad hoc tempus usurpant disciplinae gravitatem, prisci moris observantia, caritate populi Romani praecipue conspicui" (also Massilians in terms of careful observance of obligations, following the customs of their ancestors, remarkably remind the Roman people) (Val. Max. 2.6.7). Therefore, it is not surprising that those emperors who took the greatest care of the interests of the state persecuted Christians the most consistently, and those are, Trajan and Marcus Aurelius. Leaving the activities of Christians without proper reaction meant to encourage them and others to neglect their duties towards the state. Joseph Plescia believes it should be spoken not of the struggle between Christians and pagans, but between Christianity and Romanitas, i.e. "the Roman way of life"27. There were other factors that caused hostility towards Christians, in particular, the presence of a large number of foreigners, who came from the eastern provinces, in the Christian communities. Negative reaction was also caused by the attempts of Christians to dissociate themselves from all others in a society where the life of a private person was traditionally public. Of all the "superstitions" of that time only Christianity preached an idea about its own exclusiveness $^{28}[3,90]$. Thus, the first persecution of Christians during the reign of the Severan dynasty, which took place in Africa in 197, was limited in scope and was probably committed on the initiative of the crowd.

\section{The second persecution of Christians under Septimius Severus and Alexander Severus's attitude towards the Christians}

According to Eusebius, in the tenth year of the reign of Septimius

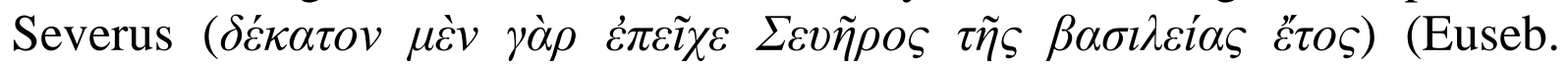
Hist. eccl. 6.2), i.e. 203, began the second persecution of Christians, which

27 Plescia J. On the persecution of the Christians in the Roman. Latomus. 1971. Fasc. 1. T. 30. P. 121-123.

28 Амосова Е.В. Спонтанные гонения на христиан как проявление кризиса античного массового сознания. Античный мир и археология. 1999. Вып. 10. С. 90. 
lasted for several years. We have a lot more information about these events. The most important sources are "Ecclesiastical history" (Historia Ecclesiastica) by Eusebius of Caesarea; biography of Septimius Severus (Vita Severi), written by Aelius Spartianus; and the Martyrdom of Saints Perpetua and Felicitas (Passio Perpetuae et Felicitatis), which is some kind of report on the suffering and death of Christian martyrs ${ }^{29}$.

The catalyst for this persecution of Christians was the edict of Septimius Severus against the Jews and Christians (201-202). According to the testimony of Aelius Spartianus, the emperor, under the penalty of punishment, forbade to convert people to Judaism (Iudaeos fieri), he also declared the same punishment for Christians (Idem etiam de Christianis sanxit) (HA. Sev. 17.1). This testimony of Aelius Spartianus forces to reject Paul Allard's assumption that the prohibition of Septimius Severus meant only the material act of circumcision. Neither can one support the assertion that Septimius Severus tried to persecute only individual Christians, and not Christianity as a whole ${ }^{30}$. Apparently, Joseph Plescia is right, arguing that this edict "was directed against Christianity, not against the Chrisitians" "31. Aleksej Lebedev rightly considers this edict as an attempt by the government to put an end to the propaganda of Christianity without encroaching on the rights of Christians. Thus, Christianity was to a certain extent recognized as an authorized religion. The law rather protected the status quo of pagan religion, especially the Roman one, than attacked religions that contradicted the dominant cult ${ }^{32}$. Andrzej Wypustek allows for the possibility that the key to understanding the edict of Septimius Severus must be sought first of all in the struggle against magic and divination. The researcher believes that this was the basis for the behavior of Septimius Severus and his officials ${ }^{33}$.

The peculiarity of this wave of persecution was that they probably occurred throughout the Empire, or, as Paulus Orosius said, in different provinces (per diversas provincias) (Oros. 7.17.4), and among numerous martyrs there were many neophytes. According to Eusebius, a particularly large number of martyrs were in Alexandria, where they were brought from all over Egypt. Among the executed in Alexandria was Leonidas,

${ }^{29}$ Robinson J.A. The Passion of S. Perpetua. Newly edited from the MSS. with an introduction and notes; together with an appendix containing the original Latin text of the Scillitan martyrdom. Cambridge : The University Press, 1891. P. 60-95.

30 Аллар П. Христианство и Римская империя от Нерона до Феодосия. Санкт-Петербург : Синоид. Тип., 1898. С. $71-74$.

${ }^{31}$ Plescia J. On the persecution of the Christians in the Roman. Latomus. 1971. Fasc. 1. T. 30. P. 124.

32 Лебедев А.П. Эпоха гонений на христиан и утверждение христианства в Греко-римском мире при Константине Великом. Москва : Изд-й отдел Спасо-Преображенского Валаамского Ставропигиального монастыря, 1994. С. 228-231.

33 Wypustek A. Magic, Montanism, Perpetua, and the Severan Persecution / A. Wypustek. Vigiliae Christianae. 1977. Vol. 51. № 3. P. 285. 


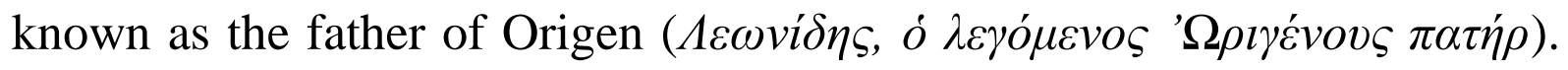
Another distinguishing feature of the persecution of 203 was that its initiative came from the emperor, as the Eusebius clearly says that it was Severus who began to persecute the churches: " $\Omega_{\varsigma} \delta \dot{\varepsilon} \kappa \alpha i ̀ ~ \Sigma \varepsilon v \tilde{\eta} \rho o \varsigma \delta \imath \omega \gamma \mu \grave{\nu} v$

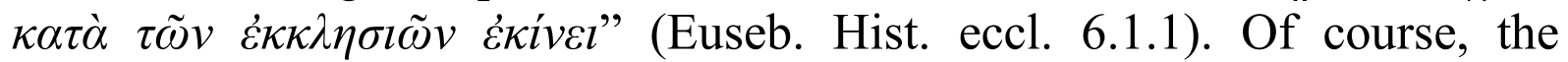
emperor did not prepare the decrees (constitutiones principium) personally. Such issues were dealt with by the personal secretary of the emperor $a b$ epistulis. The department headed by him practically managed the entire administration: it prepared instructions for officials, rescript and edicts that were issued on behalf of the emperor and sent throughout the entire Empire (magnum late dimittere in orbem Romulei mandata ducis), controlled troops and state borders (viresque modosque imperii tractare manu) (Stat. Silv. 5.1.86-88).

The fact that the edict of Septimius Severus mentioned simultaneously Jews and Christians testifies to the fact that at that time Christians were regarded as being related to the Jews. However, it was at that time that the percentage of non-Jews increased among newly converted Christians. Apparently, the number of Christians from the Gentiles surpassed the number of Christians from the Jews around the middle of the $2^{\text {nd }}$ century. Saint Justin, who wrote the first Apology during the reign of Antoninus Pius, claimed that the Christians of the Gentiles were more numerous ( $\pi \lambda$ ciovós) than the Christians of the Jews and Samaritans (Justin. Apol. 1.53.3). At that time, Latin became the language of the Western Church ${ }^{34}$. The Jews were particularly in disgrace with Septimius Severus because of the uprising that they had attempted to raise shortly after his rise to power (HA. Sev. 16.7; Oros. 7.17.3). But one may agree that it was the Christians who were the main target of Septimius Severus's decree ${ }^{35}$. This is confirmed by Eusebius's testimony that during the persecution there were cases of conversion of Christians to Judaism (Euseb. Hist. eccl. 6.12). This edict was the last act of the Roman government, directed against the Jews and the Christians at the same time.

Thus, increasing the share of non-Jews in newly converted Christians could be another motive for Septimius Severus's decree against Christians. Saints Felicitas and Perpetua, probably, took a martyr's death at the Carthage amphitheater on March 7, 203, although the date is debatable, it might have been year 202 or $204^{36}$. Saint Perpetua recorded herself

${ }^{34}$ Dudley D. The civilization of Roma. New York : New American Library; London : New English Library, 1962. P. 234.

${ }^{35}$ Frend W.H.C. Persecutions: genesis and legacy / The Cambridge History of Christianity / Ed. by Margaret M. Mitchell \& Frances M. Young. Cambridge : Cambridge University Press, 2006. Vol. I : Origins to Constantine. P. 511.

${ }^{36}$ Clarke G. Third-century Christianity / Cambridge Ancient History, $2^{\text {nd }}$ ed. Cambridge : Cambridge University Press, 2005. Vol. XII. P. 618. 
everything that happened to her, up till the moment of her martyr's death. Subsequently, these records were edited and published, perhaps by Tertullian $^{37}$. Saint Perpetua, like many other martyrs, had to endure not only the physical pain, but also the moral one. After all, by her martyrdom, she inflicted a terrible blow on her parents who did not share her desire for martyrdom. Thus, she deprived herself of the opportunity to see her newborn son grow. Saint Perpetua's father, until the last minute, in vain persuaded his beloved daughter to retreat and save her life (Passio S. Perpetuae 2). Father's visit to the imprisoned showed that Saint Perpetua belonged to two different worlds. Although the Christian community was more important for her, she was still in another world - her family's one ${ }^{38}$.

The decree of Septimius Severus did not change the legal status of Christians. Christianity remained a forbidden religion; its followers were to be executed. But officially searched for and executed were only neophytes. Paul Keresztes rightly points out that the edict of Septimius Severus led to a single real, but really important, change. Unlike Trajan's prohibition to hunt for Christians: Conquirendi non sunt (Plin. Ep. 10.97), Septimius Severus authorized the search of proselytes. Although now the authorities did not have to wait for denunciations, the search for neophytes, as the historian correctly observed, depended on the initiative of the provincial authorities ${ }^{39}$.

Tertullian gives examples of the brutal persecution of Christians by the provincial administration, as well as of sympathetic attitude towards them (Tert. ad Scap. 3-5). At the same time, it should be kept in mind that there were the persecutions of Christians, which would have taken place without the edict of Septimius Severus, as they had happened earlier, and could have continued and probably did continue.

If Septimius Severus's tolerance to Christians gives rise to serious doubts, then the attitude of another representative of the same dynasty, Alexander Severus, may be determined with a greater degree of certainty. Like Antoninus Pius, he was called "pious" (pius) and "virtuous" (sanctus) (HA. Alex. Sev. 4.5). Aelius Lampridius states that, in the morning Alexander made oblations (rem divinam faciebat) in the lararium (in larario). There were the images of the ancestors at his lararium, the very

\footnotetext{
${ }^{37}$ Robinson J.A. The Passion of S. Perpetua. Newly edited from the MSS. with an introduction and notes; together with an appendix containing the original Latin text of the Scillitan martyrdom. Cambridge : The University Press, 1891. P. $56-57$.

${ }^{38}$ Van Den Eynde S. "A Testimony to the Non-Believers, A Blessing to the Believers". The Passio Perpetuae and the Construction of a Christian Identity / More than a memory : the discourse of martyrdom and the construction of Christian identity in the history of Christianity / Ed. By Johan Leemans. Leuven : Peeters, 2005. P. 43.

${ }^{39}$ Keresztes P. The Emperor Septimius Severus : a Precursor of Decius. Historia. 1970. Bd. 19, H. 5. P. 573, 577-578.
} 
best ones, chosen (optimos electos) deified principes, as well as of some just people. Among those the historian names Apollonius, Abraham, Orpheus and Christ (HA. Alex. Sev. 29.2). There is no sufficient reason to object strongly the statement about the image of Christ. It echoes the information about Alexader's tolerance towards Christians, about his plan to build a temple for Christ and the support of Christians in the conflict regarding the land plot with the innkeepers (popinarii) (HA. Alex. Sev. 22.4; 43.6; 49.6).

Perhaps something from the reports of Alexander Severus's attachment to Christians is not true. Doubtful is the story that he gave a command to write in the Palatine palace an utterance from the Gospel, which he heard from some of the Jews or Christians: "What you do not wish that a man should do to you, do not do to him" (Quod tibi fieri non vis, alteri ne feceris) (HA. Alex. Sev. 51.8). However, the tolerant attitude of this emperor to Christians is certainly undoubted. As Eusebius renders, Julia Mammea, the mother of Alexander Severus, was not only versed in Christian doctrine, she also met with Origen, a well-known Christian writer

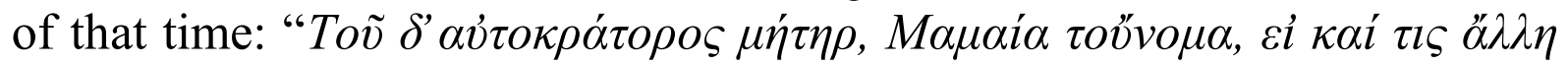

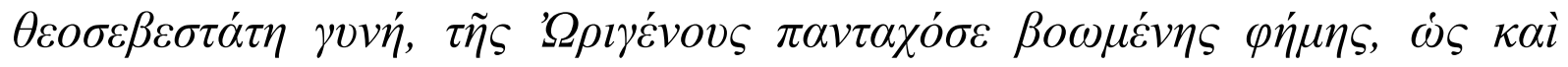

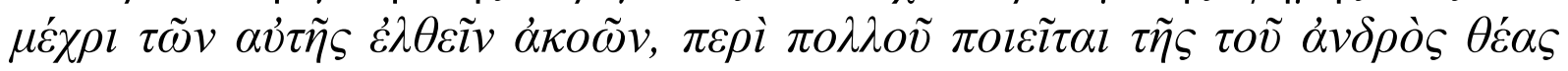

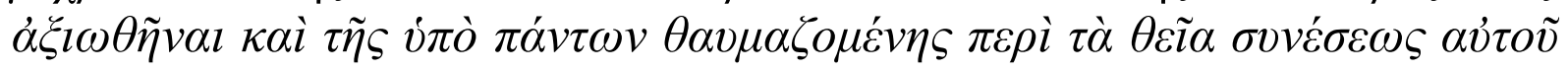

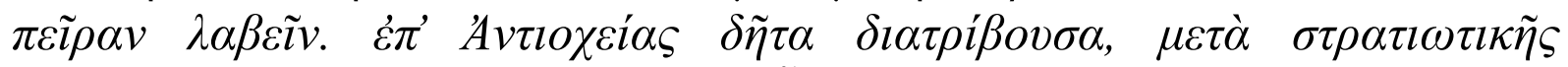

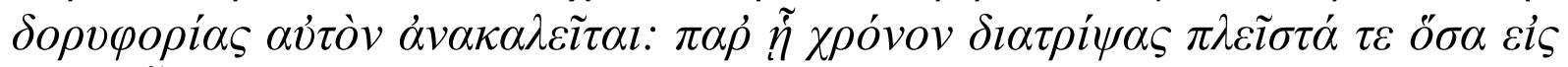

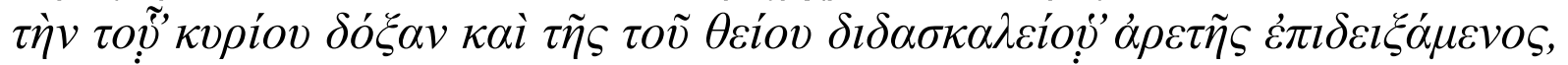

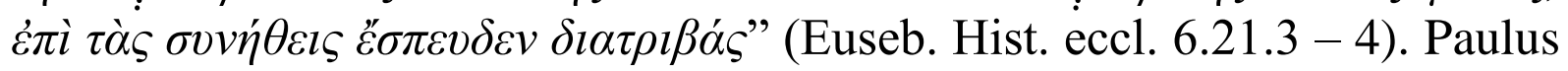
Orosius even calls her a Christian (Oros. 7.18.7). It must be recognized that the emperor was under the strong influence of his mother (Eutr. 8.23). But the reign of Alexander Severus did not bring any improvement to the legal status of Christians.

In the conflict between the Empire and Christianity, one of the parties was to be destroyed or to give something in. According to Borys Łapicki, Christians settled for a compromise, the essence of which was formulated by Apostle Paul ${ }^{40}$. In his epistle to the Romans, which can be dated year $59^{41}$, he noted: "Any soul $\left(\pi \check{\alpha} \sigma \alpha \psi v \chi \chi^{\prime}\right)$ let it be submissive to the supreme authority ... not only because of the fear of punishment, but also

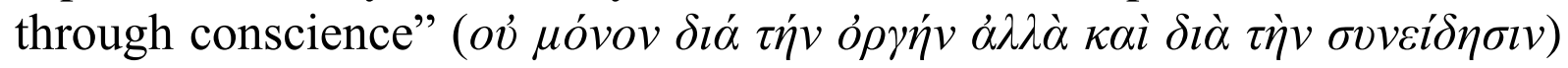
(Paul. Romans 13.1; 5).

${ }^{40}$ Łapicki B. Etyczna kultura Starożytnego Rzymu a wczesne chrześcijaństwo. Łódź : Zakład Narodowy im. Ossolińskich we Wrocławiu, 1958. S. 290.

${ }^{41}$ Толковая Библия. Петербургъ : приложение къ журналу «Странникъ», 1912. Т. 10. С. 391. 
In the First Epistle of Paul to Timothy he emphasizes that we must pray for the kings $(i \pi \varepsilon \rho \beta \alpha \sigma i \lambda \varepsilon \omega v)$ and all who are in power (Paul. 1 Tm. 2.1 - 2). Tertullian notes: "A Christian knows that the emperor is set up by his God (sciens a Deo suo constitui) and one must love, fear and respect Him, and wish Him prosperity along with the welfare of the entire Roman Empire". Therefore, says Tertullian, "we make oblations for the health of the emperor, but to our God (Itaque et sacrificamus pro salute imperatoris, sed Deo nostro) and we pray for the health of the emperor (oramus pro salute imperatoris)" (Tert. Ad Scapul. 2.6; 8 -9). It is this very practice that contributed to the fact that in the relations between Christians and authorities in the second - third centuries there were long non-conflict periods. During centuries, the confrontation between Rome and Christianity only rarely reached a high level ${ }^{42}$.

\section{CONCLUSIONS}

In sum, we shall state the following: at the end of the first century BC necessary prerequisites for the successful establishment of Christian ideology in Roman society were formed. In this context, it should be mentioned that the Roman, who was a true follower of traditional Roman beliefs, was, more likely, ready to accept the basic postulates of the Christian religion. For the Romans, the idea of the existence of the soul after the death of the body was not new. It was new that Christianity told not only about the existence of the soul after the death of the body, but also about the salvation of the soul. However, this fact, obviously, should not have caused a negative reaction in Roman society. Not surprisingly, at the end of the second century, the number of Christians increased significantly. It increased the risk of conflict situations between them and the rest of society. This was facilitated by the intensification among the Christians of factions with extremist views, in particular, Montanists.

Under the Severan dynasty the legal status of Christians, in general, has not changed. Christianity remained a forbidden religion. The persecution of Christians in 197 was limited in scope and was probably based on the initiative of the crowd. The catalyst of the persecutions in 203 was the edict of Septimius Severus, which forbade the conversion to Judaism and Christianity, but was directed primarily against Christians. The main reasons for the publication of this edict were probably: firstly $-\mathrm{a}$ sharp increase in the number of Christians and activation among them of the supporters of Montanism; secondly - the growth of the proportion of non-Jews among the proselytes; and thirdly - the identification of

${ }^{42}$ Bryan C. Render to Caesar : Jesus, the early church and the Roman superpower. Oxford : Oxford University Press, 2005. P. 115. 
Christians as proponents of magic and divination. The duration and intensity of persecution was uneven in different provinces. The tolerant attitude of Alexander Severus to Christians should not be questioned, but his reign did not bring any improvement to the legal status of Christians.

From the second half of the $2^{\text {nd }}$ century AD one can speak of an increase among Christians of the spirits for more active participation in the official institutions of the Roman state, including the army. We can state that Christians came to a compromise with the Roman government. It is this very practice that contributed to the fact that in the relations between Christians and authorities in the $2^{\text {nd }}-3^{\text {rd }}$ centuries there were long nonconflict periods.

\section{SUMMARY}

The article deals with the policy of the Severan dynasty toward Christianity. It has been determined that under the Severan dynasty the legal status of Christians, in general, has not changed. Christianity remained a forbidden religion. It has been proven that the catalyst of the persecutions in 203 was the edict of Septimius Severus, which forbade the conversion to Judaism and Christianity, but was directed primarily against Christians. The main reasons for the publication of this edict were probably: firstly - a sharp increase in the number of Christians and activation among them of the supporters of Montanism; secondly - the growth of the proportion of non-Jews among the proselytes; and thirdly the identification of Christians as proponents of magic and divination. From the second half of the $2^{\text {nd }}$ century one can speak of an increase among Christians of the spirits for more active participation in the official institutions of the Roman state, including the army. It is asserted that Christians came to a compromise with the Roman government. It is this very practice that contributed to the fact that in the relations between Christians and authorities in the $2^{\text {nd }}-3^{\text {rd }}$ centuries there were long nonconflict periods.

\section{REFERENCES}

1. Aubé B. Les chrétiens dans 1'Empire Romain de la fin des Antonins au milieu du IIIe siècle. Paris : Didier et Cie, 1881. vi, 530 p.

2. Barnes T.D. Legislation against the Christians. The Journal of Roman Studies. 1968. Vol. 58, Parts 1-2. P. 32-50.

3. Bryan C. Render to Caesar : Jesus, the early church and the Roman superpower. Oxford : Oxford University Press, 2005. xii, 185 p.

4. Canfield L.H. The early persecutions of the Christians. New York : Columbia University, 1913. 215 p. 
5. Clarke G. Third-century Christianity / Cambridge Ancient History, $2^{\text {nd }}$ ed. Cambridge : Cambridge University Press, 2005. Vol. XII. P. 589-672.

6. Crake J.E.A. Early Christians and Roman law. Phoenix. 1965. № 1. Vol. 19. P. 61-70.

7. Dudley D. The civilization of Roma. New York : New American Library; London : New English Library, 1962. 256 p.

8. Fishwick D. The Imperial Cult in the Latin West : studies in the ruler cult of the western provinces of the Roman Empire. Leiden : Brill, 1987. Vol. 1.2. vii, 195-371 p.

9. Frend W.H.C. Persecutions: genesis and legacy / The Cambridge History of Christianity / Ed. by Margaret M. Mitchell \& Frances M. Young. Cambridge : Cambridge University Press, 2006. Vol. I : Origins to Constantine. P. 503-523.

10. Gero S. "Miles Gloriosus": The Christian and military service according to Tertullian. Church History. 1970. № 3. Vol. 39. P. 285-298.

11. Gibbon E. The decline and fall of the Roman Empire. New York : Peter Fenelon Cooper, 1899. Vol. I. 590 p.

12. Janssen L.F. "Superstitio" and the Persecution of the Christians. Vigiliae Christianae. 1979. № 2, Vol. 33. P. 131-159.

13. Hammond M. Septimius Severus, Roman bureaucrat. Harvard Studies in Classical Philology. 1940. Vol. 51. P. 137-173.

14. Helgeland J. Christians and the Roman Army A.D. 173-337. Church History. 1974. № 2. Vol. 43. P. 149-163.

15. Kenrick J. Roman sepulchral inscriptions : their relation to archaeology, language, and religion. London ; York : John Russell Smith ; R. Sunter ; H. Sotheran, 1858. viii, 70 p.

16. Keresztes P. The Emperor Septimius Severus : a Precursor of Decius. Historia. 1970. Bd. 19, H. 5. P. 565-578.

17. Klauck H.J. The Roman Empire / The Cambridge History of Christianity / Ed. by Margaret M. Mitchell \& Frances M. Young. Cambridge : Cambridge University Press, 2006. Vol. I : Origins to Constantine. P. 69-83.

18. Łapicki B. Etyczna kultura Starożytnego Rzymu a wczesne chrześcijaństwo. Łódź : Zakład Narodowy im. Ossolińskich we Wrocławiu, 1958. $322 \mathrm{~s}$.

19. Moore C.H. Pagan ideas of immortality during the Early Roman Empire. Cambridge : Harvard University Press, 1918. 64 p.

20. Petrechko O. A burial rite of the Romans in the context of the ancient society conception of the soul // Проблеми гуманітарних наук : збірник 
наукових праць Дрогобицького державного педагогічного університету ім. I. Франка. Серія “Історія”. 2016. Випуск 38. Р. 246-267.

21. Phipps C.B. Persecution under Marcus Aurelius. An historical hypothesis. Hermathena. 1932. № 47. Vol. 22. P. 167-201.

22. Plescia J. On the persecution of the Christians in the Roman. Latomus. 1971. Fasc. 1. T. 30. P. 120-132.

23. Ramsay W.M. The Church in the Roman Empire. London : Hodder and Stoughton, 1893. xvi, 494 p.

24. Robinson J.A. The Passion of S. Perpetua. Newly edited from the MSS. with an introduction and notes; together with an appendix containing the original Latin text of the Scillitan martyrdom. Cambridge : The University Press, 1891. viii, 131 p.

25. Sherwin-White A.N. The early persecutions and Roman law again. The Journal of Theological Studies. 1952. Vol. III, issue 2. P. 199-213.

26. Sherwin-White A.N. The letters of Pliny : a historical and social commentary. Oxford : Clarendon Press, 1966. xv, 805 p.

27. Smith R.E. The army reforms of Septimius Severus. Historia. 1972. № 3. Bd. 21, H. 3. P. 481-500.

28. Suski R. Jowisz, Jahwe i Jezus : religie w Historia Augusta. Warszawa : Wydawnictwo Naukowe Sub Lupa, 2014. 472 s.

29. Van Den Eynde S. "A Testimony to the Non-Believers, A Blessing to the Believers". The Passio Perpetuae and the Construction of a Christian Identity / More than a memory : the discourse of martyrdom and the construction of Christian identity in the history of Christianity / Ed. By Johan Leemans. Leuven : Peeters, 2005. P. 23-44.

30. Wypustek A. Magic, Montanism, Perpetua, and the Severan Persecution / A. Wypustek. Vigiliae Christianae. 1977. Vol. 51. № 3. P. 276-297.

31. Абрамзон М.Г. Монеты как средство пропаганды официальной политики Римской империи. Москва : Институт археологии Российской Академии наук, 1995. 656 с.

32. Аллар П. Христианство и Римская империя от Нерона до Феодосия. Санкт-Петербург : Синоид. Тип., 1898. vi, 292 с.

33. Амосова Е.В. Спонтанные гонения на христиан как проявление кризиса античного массового сознания. Античный мир $и$ археология. 1999. Вып. 10. С. 88-97.

34. Донини А. У истоков христианства (от зарождения до Юстиниана). М. : Политиздат, 1989. 365 с.

35. Казаков М.М. Проблема христианизации Римской империи. Исследования по зарубежной истории. Смоленск, 2000. С. 196-204. Режим доступа : http://ancientrome.ru/publik/article. htm?a=1405377993. 
36. Крист К. История времен римских императоров от Августа до Константина : в 2-х т. Ростов н/Д. : Феникс, 1997. Т. 2. 509 с.

37. Лебедев А.П. Эпоха гонений на христиан и утверждение христианства в Греко-римском мире при Константине Великом. Москва : Изд-й отдел Спасо-Преображенского Валаамского Ставропигиального монастыря, 1994. 400 с.

38. Сергеев И. П. Римская империя в III веке нашей эры. Проблемы социально-политической истории. Харьков : Майдан, 1999. $224 \mathrm{c}$.

39. Толковая Библия. Петербургъ : приложение къ журналу “Странникъ”, 1912. Т. 10.519 с.

40. Федосик В.А. Киприан и античное христианство. Минск : Университетское, 1991. 208 с.

Information about the author: Petrechko O. M.

Doctor of Sciences in History, Professor, Head of the World History and Special Historical Disciplines Department, Drohobych Ivan Franko State Pedagogical University 24, Ivan Franko str., Drohobych, 82100, Ukraine 